\title{
Impact of climate change on waterborne diseases
}

\author{
Enzo Funari ${ }^{(a)}$, Maura Manganelli ${ }^{(a)}$ and Luciana Sinisi ${ }^{(b)}$ \\ ${ }^{(a)}$ Dipartimento di Ambiente e Connessa Prevenzione Primaria, \\ Istituto Superiore di Sanità, Rome Italy \\ (b) Istituto Superiore per la Protezione e la Ricerca Ambientale, Rome, Italy
}

\begin{abstract}
Change in climate and water cycle will challenge water availability but it will also increase the exposure to unsafe water. Floods, droughts, heavy storms, changes in rain pattern, increase of temperature and sea level, they all show an increasing trend worldwide and will affect biological, physical and chemical components of water through different paths thus enhancing the risk of waterborne diseases. This paper is intended, through reviewing the available literature, to highlight environmental changes and critical situations caused by floods, drought and warmer temperature that will lead to an increase of exposure to water related pathogens, chemical hazards and cyanotoxins. The final aim is provide knowledge-based elements for more focused adaptation measures.

Key words: climate change, waterborne diseases, microbial pathogens, chemical contaminants, toxic cyanobacteria.

Riassunto (Effetto dei cambiamenti climatici sulle malattie trasmesse dall'acqua). I cambiamenti climatici e del ciclo idrologico metteranno a rischio la disponibilità d'acqua e aumenteranno l'esposizione ad acqua contaminata. Le alluvioni, le siccità, le grandi tempeste, le variazioni nella frequenza ed intensità delle piogge, il riscaldamento e l'aumento del livello del mare crescono in ogni parte del mondo e influenzeranno le caratteristiche biologiche e chimico-fisiche dell'acqua attraverso diversi meccanismi, con il conseguente aumento del rischio di malattie trasmesse dall'acqua. L'analisi della letteratura disponibile, presentata in questo articolo, evidenzia i cambiamenti ambientali e le situazioni critiche causate da alluvioni, siccità e crescente riscaldamento che causeranno un aumento di esposizione a patogeni, inquinanti chimici e cianotossine, legati all'acqua. Lo scopo è di fornire gli elementi scientifici di base per misure di adattamento mirate.
\end{abstract}

Parole chiave: cambiamenti climatici, malattie trasmesse dall'acqua, microrganismi patogeni, contaminanti chimici, cianobatteri tossici.

\section{INTRODUCTION}

Climate variability and change may greatly influence human health [1], directly, as for instance drowning or trauma in extreme weather events, or indirectly, by altering the characteristics of the natural environments and habitats hence increasing the exposure of human populations to risk factors.

Extreme weather events are by far among the most destructive disasters known, whether their toll is measured in lives, damages of built environment, destruction of critical infrastructure, loss of properties and economic activities, irreversible contaminations, forced population displacement, short and long term diseases. According to EM-DAT [2] disastrous weather events database (criteria to be accounted for EM-DAT data base: a) at least 10 people killed; b) more than 100 hundred people affected; c) call for international assistance; d) declaration of state of emergency), the number of affected people in the UN-ECE Euro Region in the last two decades has increased of about $400 \%$ compared to previous decadal period. Up to the first semester of 2008, as a consequence of adverse meteorological disasters, 38 million people required health assistance and basic survival needs such as safe shelter, medical assistance, a safe water supply and sanitation. EU accounted for 29 million of affected people with an economic loss of about 270 US\$ billion, the highest rate in the world of economic loss per capita. In particular, Italy and Germany suffered major damages from floods and storms due to high population and infrastructure density. The overall scenario in the western hemisphere is similar. In the US more than 700 billion US\$ in damages were estimated for the period 1980-2008, mostly due to hurricane, severe weather and non-tropical floods. Trends constantly increased worldwide and they're expected to do the same in the future since, as stated in the latest 2012 IPCC SREX Report [3], observed changes in climate extremes reflect the influence of anthropogenic climate changes in addition to natural climate variability, with changes in exposure and vulnerability influenced by both climatic and no climatic factors. Specifically about floods, it is 
likely that the frequency of heavy precipitations or the proportion of total rainfall from heavy rainfalls will increase in the $21^{\text {st }}$ century over many areas of the globe. This is particularly the case in the high latitudes and tropical regions, and in winter in the northern mid-latitudes. Heavy rainfalls associated with tropical cyclones are likely to increase with continued warming induced by enhanced greenhouse gas concentrations. There is high confidence that locations currently experiencing adverse impacts such as coastal erosion and inundation will continue to do so in the future due to increasing sea levels, all other contributing factors being equal [3].

In the temperate zone, climate change is predicted to decrease the number of rainy days, but to increase the average volume of each rainfall event [4]: as a consequence, drought-rewetting cycles may impact water quality as it enhances decomposition and flushing of organic matter into streams [5]. Flooding is the most common natural extreme weather event in the European Region [2]. Flooding may be caused by heavy rainfall, tidal surges and rapid snow melt. According to a database on floods in Europe, the most extreme flash floods are greater in magnitude in the Mediterranean countries than in the inner continental countries [6]. Coastal flooding related to increasing frequencies and intensities of storms and Sea Level Rise (SLR) is likely to threaten up to 1.6 million additional people annually in the EU alone [7]. Larger storm surges produced by extreme storms, combined with a rising sea level, could result in much higher rates of coastal erosion, which would in turn affect the levels of saline intrusion into coastal freshwater [8].

Other climatic factors affecting the hydrological regime are temperature and droughts, both of them projected to become worse.

About temperature, models predict with large confidence a substantial warming in temperature extremes by the end of the $21^{\text {st }}$ century. Also, on a global scale, the frequency and magnitude of warm daily temperature extremes will increase, while cold extremes will decrease. The frequency of annual hottest days are projected to go from 1 in 20 years to 1 in 2 years, with an increase in the annual daily temperature of 2 to $5{ }^{\circ} \mathrm{C}$ by the end of $21^{\text {st }}$ century, even if regional variations will often differ from the global changes [3].

These phenomena are going to affect many characteristics of water basins, as it has already happened. Atmospheric warming has been associated with an increase in surface water temperatures since the 1960s in Europe, North America and Asia (0.2$2{ }^{\circ} \mathrm{C}$ ) [4]. In several lakes in Europe and Northern America, the water temperature increase has influenced the stratification period that has lengthened by 2-3 weeks [9]. In the European rivers Rhine and Meuse, an increase in the average summer water temperature of about $2{ }^{\circ} \mathrm{C}$ has been observed over the last three decades, with temperature peaks during the two severe droughts in 1976 and 2003, with a $\mathrm{pH}$ increase (due to a decrease in $\mathrm{CO}_{2}$ concentration) [10-11]. Computer models predict an increase of around $2^{\circ} \mathrm{C}$ by 2070 in European lakes, although differences can be estimated, depending on lake characteristics and season [12-13]. The residence time in lakes with, at present, a short residence time, will probably increase by $92 \%$ in 2050 in summer and there will be a significant increase in temperature in the epilimnion and hypolimnion in shallow lakes [13]; however, on a long period, deepest lakes will be most sensitive to warming, due to their higher heat storage capacity and will experience highest winter temperature [14].

Also the ocean state has changed, in response to changed surface thermal conditions. The heat content of the World Ocean has increased since 1955, leading to sea level rise through thermal expansion, in addition to transfer of mass from glaciers, ice sheets and river runoff, due to changing hydrological regime. The waters at high latitudes (poleward of $50^{\circ} \mathrm{N}$ and $70^{\circ} \mathrm{S}$ ) are fresher in the upper $500 \mathrm{~m}$, while the subtropical latitudes in both hemispheres are characterized by increase in salinity. However, while there are many robust findings regarding the changed ocean state, key uncertainties still remain, making difficult projections for the future [15].

Droughts, which can be described as an unusual long period with little or no precipitation, are expected to increase in some areas. Model projections for the next 50-100 years indicate that climate change will reduce discharges to coastal waters in southern South America, western Australia, western and southern Africa, and in the Mediterranean Basin with consequences on salinities and nutrients and sediment delivered to the coast [16]. Salinity will tend to advance upstream, thereby altering the zonation of plant and animal species as well as the availability of freshwater for human use. Saltwater intrusion as a result of a combination of sea-level rise, decreases in river flows, unsustainable freshwater withdrawal and increased drought frequency are expected to modify physical and chemical components of estuarine-coastal environments with secondary impacts on phytoplankton community. In Central and Southern Europe and the Mediterranean region, in North and Central America, northeast Brazil and Southern Africa, droughts will likely intensify in the $21^{\text {st }}$ century, due to reduced precipitation and/or increased evapotranspiration [3]. Projection for the rest of the world are still inconsistent, due to lack of data, or incapacity of the model to include all the different causes of dryness [3].

During dry periods, reduced groundwater recharge and increased water abstraction due to warmer temperatures may cause further water stress by reducing groundwater table levels. For these reasons in coastal areas, droughts can cause the intrusion of seawater into freshwater aquifers. In general freshwater contamination by seawater of only $5 \%$ is enough to rule out many important uses including drinking-water supply, irrigation of crops, parks and gardens, and 
the well-being of groundwater- dependent ecosystems [17].

To identify the role of climate change on the spreading of waterborne diseases is made difficult by the simultaneous influence of other causes, like destruction of habitats, extensive travels and migrations of human populations, drug and pesticide resistance, urbanization and increased population density, and availability of health services [18].

The aim of this paper is to review the available literature to show the potential increase of the burden of WBDs resulting from climate changes and particularly from floods, increase of temperature and droughts, with regards to risk factors as microbial pathogens, chemicals, cyanotoxins.

\section{MICROBIAL PATHOGENS}

Waterborne pathogens of human and animal faecal origin include a high number of viruses, bacteria and parasitic protozoa. Also several naturally occurring microorganisms can be pathogenic to humans, as various species of Vibrio (gastroenteritis, diahorraea and septicemia), Pseudomonas aeruginosa (skin and ear infections), Legionella pneumophila (Legionnaire's disease) and amoebae (encephalitis) [19].

Waterborne pathogens of concern for humans have the following characteristics:

- "are shed into the environment in high numbers, or are highly infectious to humans or animals at low doses" (i.e. cystis of protozoa);

- "can survive and remain infectious in the environment for long periods, or they are highly resistant to water treatment;

- some types of bacterial pathogens can multiply outside of a host under favorable environmental conditions" [20]. Pathogenic microorganisms of human and animal faecal origin enter surface waters mainly by discharges of raw and treated wastewater and by runoff from the land. The reservoirs and routes of exposition are schematically depicted in Figure 1, after Hurst [21]. Some pathogens, like V. cholerae, hepatitis A virus and Schistosoma are restricted to tropical areas, while others like Cryptosporidium and Campylobacter are more diffused [22].

\section{Heavy rainfall and floods}

More frequent and intense heavy rainfall/floods will cause higher pathogen concentrations in natural waters which will generally be reflected in worse quality of drinking and bathing waters, crops and shellfish. Indeed, heavy rainfall/floods can cause over-flooding of sewage treatment plants, runoff of animal dejections and manure, re-mobilisation and redistribution of contaminated sediments [7, 23-27]. Since the diffusion of pathogens depends on hydrodynamic of surface water bodies it can be expected that floods and heavy rainfall, by speeding up water fluxes carrying pathogens, will counteract the natural pathogen inactivation in the environment by UV and temperature.

Enhanced environmental levels of pathogenic microorganisms may result in increased incidence of diseases and occurrence of new ones [28]. In general it is expected that zoonotic infections may expand due to an increased washing into water of wild animal and livestock faeces. A significant problem can be posed by an increased presence of different strains of enteric viruses in water bodies, as they are resistant to treatment in sewage treatment plants; bathing water receiving treated waters and seafood reared in receiving water bodies can represent important source of exposure to these pathogens [29]. Furthermore, viruses can be the unseen etiological pathogens responsible for human diseases even

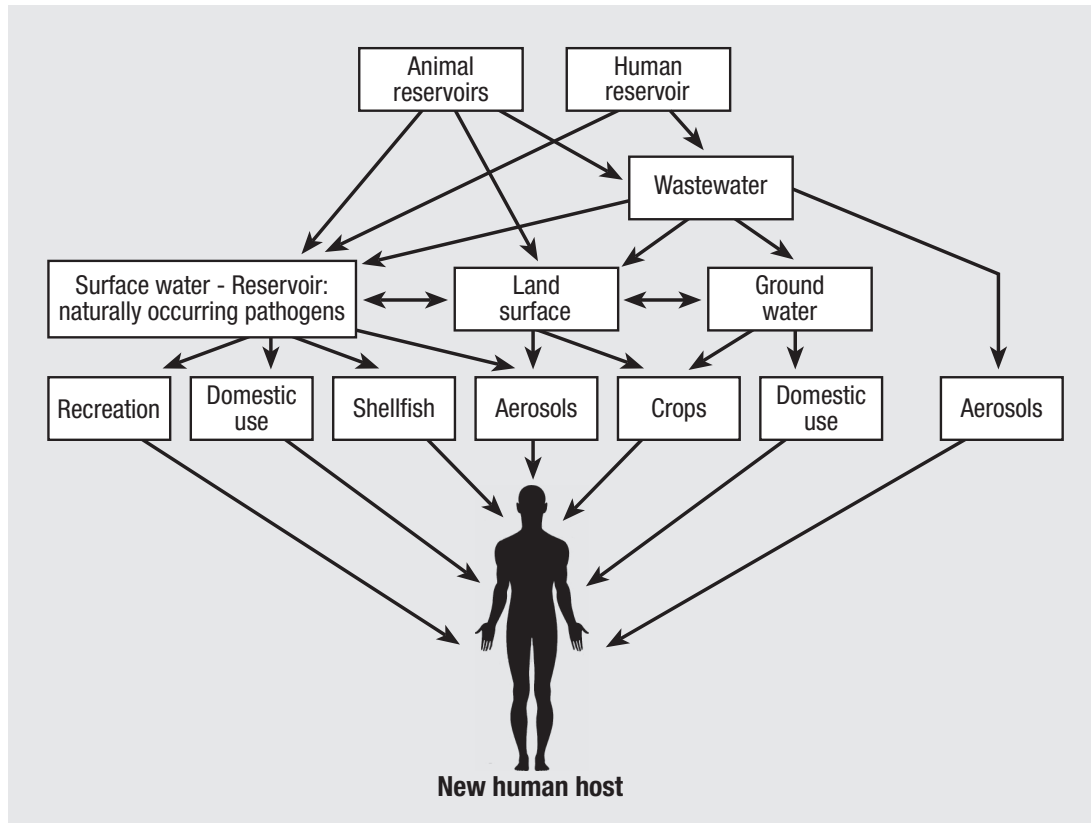

Fig. 1 | Sources of waterborne pathogen. The non-enteric pathogens are naturally present in surface waters, which can, therefore be a reservoir. (Modified from Hurst [21]). 
when waters meet regulatory criteria for faecal contamination, based on conventional bacterial indicators, which are less resistant than viruses and decay much faster in natural environment [29]. Studies on cryptosporidiosis suggest that in the future more intense precipitation events may increase the saturation of soil profiles and mobilize infectious oocysts more often, significantly increasing the risk [30].

There are several examples of waterborne diseases outbreaks associated to excessive rainfall [3143]. The largest reported waterborne disease outbreak in the United States, due to the presence of Cryptosporidium cists in drinking water, occurred in Milwaukee in 1993 and was related to heavy rainfall and associated runoff and consequent contamination of Milwaukee lake, the source of the waterworks of the area. It resulted in the deaths of 54 people and more than 403000 ill [37, 44]. Contamination of groundwater after flooding has been associated to additional disease outbreaks like Acanthamoeba keratitis in Iowa (USA) [22]. An outbreak of giardiasis in Montana (USA) was related to excess rainfall [39]. Cryptosporidiosis cases in England and Wales were positively associated with maximum river flow [45]. Escherichia coli $\mathrm{O} 157: \mathrm{H} 7$ and Campylobacter jejuni were responsible for a waterborne outbreak, causing 7 deaths, 65 hospitalization and more than 2300 cases of gastrointestinal illness in the Canadian town of Walkerton [46]. In this case, drinking water, supplied by shallow groundwater wells, turned out to be contaminated by a cattle manure from a local farm, following a period of intense spring rainfall, an event that is considered to happen once every 60 years [46].

In the US, Curriero et al. [38] reported a statistically significant association between excess rainfall and waterborne disease outbreaks over a long period of time and on a national scale. The study was based on 548 reported outbreaks in the United States from 1948 through 1994 . The results indicated that 51\% of waterborne disease outbreaks were preceded by rainfall events above the 90th percentile and that $68 \%$ were preceded by events above the 80 th percentile. Outbreaks due to groundwater contamination were preceded by a 2-mo lag in rainfall accumulations whereas surface-water contamination showed the strongest association with excessive rainfall during the month of the outbreak [38].

In the European Union, in 2007, only 17 waterborne outbreaks were reported by eight countries, clearly indicating an under-reporting; they involved 10912 cases, with 232 hospitalizations. The main microorganisms involved were Campylobacter, norovirus, Giardia and Cyptosporidium [47]. Only 24\% of waterborne pathogen outbreaks in England, between 1970 and 2000, were found associated to heavy rainfall [48]. Yet, Nichols et al. [36] analyzing a small dataset [89] of waterborne outbreaks in England and Wales between 1910-1999, due to Giardia, Cryptosporidium, E. coli, S. typhi, S. paratyphi, Campylobacter and Streptobacillus mon- iliformis, assessed a significant strong correlation between $40 \%$ of the cases and heavy rainfall in the week before the outbreak or low rainfall during the four weeks preceding the outbreaks.

Floods and hurricanes, destroying the water distribution system and mixing drinking and waste waters, can have a significant impact also on the diffusion of cholera, caused by the naturally occurring $V$. cholerae. The disease is one of the most severe forms of waterborne diarrheal disease, especially for developing countries, where outbreaks occur seasonally and are associated with poverty and use of poor sanitation and unsafe water [1]. The extreme climatic events increase the cases of diseases and fatalities by adding an oral-faecal contamination pathway difficult to manage.

Rainfalls are known to worsen the microbiological quality of bathing waters, indeed they are used directly as predictors of short term events of contamination in the European directive concerning the management of bathing water quality [49]. The same approach should be applied to shellfish-growing waters, as well. Indeed after heavy rainfalls sudden contamination of coastal waters are expected and results from environmental investigation, which require a too long time, do not represent the adequate tool to predict this contamination and prevent from dangerous human exposures. Heavy rainfall and sewage treatment plant failure were twice responsible for international gastroenteritis outbreaks due to consumption of oysters harvested from Tahu lagoon, in France [50, 51]. One of the outbreaks was characterized by the high diversity of human enteric viruses (up to six different strains) detected both in patient stool and shellfish samples [51]. Other important outbreaks associated to contaminated oyster/clam consumption caused by sewage overflow and discharge into the aquatic environment during heavy rainfall events were reported as those that affected 2000 people in Australia, in summer 1978 [52], and 1000 people in New York State in 1982 [53].

\section{Temperature}

There is a contrast between the well documented and forecasted increase in temperature and the paucity of data on the effects of this increment on microbial pathogens and infectious diseases [54].

Enteric pathogens in the water environment are generally neutralized by higher temperatures, however, their sensitivity shows different features. For instance, cysts of Giardia and enteroviruses are less rapidly inactivated compared with oocysts of Cryptosporidium [55]. Cryptosporidium oocysts are inactivated during the winter, as they are susceptible to freezing and thawing cycles; hence, as the number of frozen days decrease, oocysts may increasingly survive through the winter [30]. It is also known that a large variation in temperature susceptibility exists among viruses [56], suggesting a possible selection of more resistance strains, like the hepatitis A virus (HAV), which is fairly temperature insensitive. For some viruses a 
correlation between increasing temperature and inactivation rate starts only after 10 days [55].

Increasing temperature could favor less temperature sensitive species, directly promoting the growth of some indigenous bacteria, including pathogenic species [57]. Vibriosis caused mainly by Vibrio parahaemolyticus, $V$. vulnificus and $V$. alginolyticus are among the 6 most common foodborne diseases monitored by the Foodborne Diseases Active Surveillance Network (FoodNet) in the USA, where $V$. parahaemolyticus in the past decade has become the main cause of gastroenteritis [58]. According to CDC, the incidence of Vibrio infections in the USA, which are also monitored by the Cholera and Other Vibrio Illness Surveillance (COVIS) system and are due to exposure to recreational water as well, was $76 \%$ higher in 2011 than in 1996-1998 [59]. A strong link between rising summer water temperatures, prolonged summer seasons, and noncholera Vibrio sp. infections has been shown [60], even if Johnson et al. [61] found that temperature explain only about $50 \%$ of the presence of $V$. paraemolytichus, and also that the pathogenic subpopulations respond differently than the whole population to temperature.

The influence of increased temperatures on environmental bacteria is not expected to be homogeneous. The Baltic Sea for instance provides an environment in which only small changes of the present conditions (e.g., temperature) result in increased Vibrio sp. populations [60].

Increasing temperatures would be expected to expand the range and increase the prevalence of $V$. cholerae and cholera both geographically and temporally, if environment and public health measures are not implemented [57]. Indeed, temperature shifts will alter the latitudinal distribution of planktonic species. Due to sea level rise inland areas will experience greater saltwater intrusion and increased levels of marine and estuarine bacteria, including $V$. cholerae [57]. It is then expected that an increase in temperature will threat water quality with regard especially to cholera disease in Asia and South America [22]. However, the question may be more complex. A non linear population model to explain and predict the dynamics of $V$. cholerae has been developed by Koelle et al. [62]. The authors, considering both extrinsic (climatic) and intrinsic (acquired temporary immunity) drivers of epidemics, could explain the interannual cycles of cholera outbreaks from Matlab, Bangladesh. They found a strong correlation with climatic variables (monsoon) over 7 years and with local water temperature, degree of floods and droughts, at a shorter scale. Warmer pond and rivers increase the incidence of cholera through the faster growth rate of the pathogen in aquatic environments, but to have a good correspondance between the model and the incidence of cholera epidemics it was necessary to include in the model data on other parameters included the complex dynamics of aquired temporary immunity which could explain the interval between two epidemics [62].
There are also some authors who argued that one of the main effects of climate change is the reduction of biodiversity, that is some species are disappearing at a high rate, and that pathogens are subjected to the same ecological constraints [63]. Therefore, if there are areas where health conditions are worsening due to the spreading of pathogenic organisms, there are other areas that will be affected in the opposite way, thus reducing the areal distribution of the same pathogen. The final balance could be no overall increase in the global diffusion of a pathogenic species. The importance of such a debate is to highlight, among others, some important aspects to be considered: 1) better data sets and modeling approaches are required to make robust predictions of the impacts of climate change on disease dynamics and 2) expansion or reduction of specific pathogens geographical ranges will depend not only on extrinsic factors (including climate change), but also on intrinsic factors (such as immunity, phenotypic plasticity, and evolution) [64].

\section{Droughts}

The impacts of drought on human health due to shortage of water are dramatic and include deaths, malnutrition, increase in infectious diseases [65]. These effects are associated with worsening hygienic conditions, higher probability of microbial contamination of drinking water due to infiltration of organic material along the distribution system when pressure drops, higher re-use of wastewaters in agriculture, with consequent contamination of fresh vegetables, unsafe use of untreated water. Additionally, water shortages may increase the likelihood of multiple uses of a water body (e.g., for cleaning, bathing, and drinking) with a consequent increase of the risk of microbial contamination and human exposure to pathogens [57]. Periods of droughts followed by short intense rainfall can cause peaks of surface water contamination. River-bed sediments represent an important microorganisms reservoir in dry areas, like the Mediterranean, where long dry periods are interrupted by flashfloods, transporting most of them downstream, up to coastal waters [66]. In areas affected by increasing droughts, treated effluents from sewage plants might become a quantitatively important source of water influx into river and heavy rainfall events can pose a risk to human health because of the huge increase of pathogenic microrganisms concentrations in the river downstream sewage treatment plants. In a study on Campylobacter, it has been shown that the resulting combined sewer overflow, enriched in pathogen, is discharged into the receiving rivers at a 150 fold higher concentration than usual [67].

Drought can lower the water table, resulting in changes in underground water flows of surface water into groundwater. In UK, an outbreak of Cryptosporidium, due to contamination of the borehole used as a source of drinking water was recorded when unusually very strong rainfall followed a long dry period [68]. No conclusive explanation is 
given in the report, but the authors suggested the possible contamination of the aquifer by the intrusion of a contaminated river water flowing nearby, through interstices in the chalk [68]. Other examples of outbreaks linked to contamination of groundwater sources have been documented. In Brushy Creek, Texas, an outbreak of cryptosporidiosis was reported in 1998 followed extended drought conditions. The primary drinking water supply of Brushy Creek was chlorinated groundwater [69]. This source was contaminated by sewage, through fractures in the bedrock due to the long period of drought and extreme heat in which heavy water demand and no rainfall was present to recharge the aquifer [69]. Outbreaks of cryptosporidiosis have been associated to contamination of drinking water supplied by surface water, due to intense rainfall after very long and unusual drought periods, in Japan and Oregon [7071]. The largest reported outbreak of E. coli O157:H7 occurred at a fairground in the state of New York in September 1999 and was linked to contaminated well water. This outbreak resulted from unusually heavy rainfall, which was preceded by a drought [43].

In general, monitoring programs are not elaborated in such a way to capture these periods of very high peaks of pathogenic concentrations which in turn represent a particularly high risk of infectious diseases transmission.

\section{CHEMICALS}

Climate change may influence the concentrations of chemical constituents and contaminants in natural waters through diverse ways. As an example, coastal erosion, likely to be exacerbated under climate change, has led to the exposure of landfill sites in Europe, with a clear potential for contamination of coastal waters [27].

It is difficult to estimate the risk associated to increased chemical concentrations in natural waters. Nevertheless, it seems possible to identify the following scenario of human exposure and the respective reasons of concern.

\section{Heavy rainfall and floods}

Climate change will influence the concentration of chemical constituents in natural waters. Indeed, it has been reported that a storm flow, by increasing the concentration of dissolved organic matter to which some metals can strongly get complexed, could lead to a transport of dissolved lead, titan and vanadium in peat land systems [72]. Furthermore a seasonal change in dissolved metal concentrations has also been observed for various trace elements ( $\mathrm{Fe}, \mathrm{Mn}, \mathrm{Al}, \mathrm{La}, \mathrm{U}, \mathrm{Th}, \mathrm{Cd}$ and $\mathrm{As}$ ). An increase of organic carbon content and a decline in redox conditions seem to be related with a trace elements release. A positive correlation is also found between storm events and trace element concentrations in streams [73]. In fact, organic and inorganic colloids could play an important role in trace elements mo- bilization in soil sand water [74]. The possible implications for human health associated with these higher mobilization of chemical constituents from minerals and higher concentrations in natural waters are difficult to demonstrate. Natural waters contain many minerals, often in very small concentrations, that arise from the contact with the rocks and soils that water goes through. Most of these are of no concern but some are known they may impact human health for instance via drinking water, as arsenic and fluoride. Both arsenic and fluoride are significant contributors to morbidity in regions where concentrations in water are high. Hence, higher concentration of these elements as well as others of human concern may represent higher risky conditions in the affected areas.

More frequent intense rainfall is likely to exacerbate the flushing to water bodies of agricultural pollutants, including pesticides and veterinary medicines $[28,75]$. Flooding may lead to contamination of water other than with chemicals already in the environment like pesticides, with dangerous chemicals, heavy metals, or other hazardous substances, from storage. Overall, flood events and strong rainfalls can transport pollutants from a contaminated area to a non-contaminated one $[24,76]$, from soil and sediments to water bodies.

Drinking water treatment is vital in protecting public health against microbial illness which remains a major cause of morbidity and mortality in many parts of the world, yet care has to be taken that treatment does not introduce higher levels of unwanted disinfection by-products (DBPs) than necessary. Indeed, epidemiological studies reported weak associations between chlorination and cancers of the colon, rectum and bladder and positive associations between concentrations of DBPs and a number of adverse reproductive effects, particularly stillbirth and low weight for gestational age [77]. In the past years a significant decline in DBPs concentrations has been achieved especially thanks to the introduction of improved treatment to remove the natural organic matter and better filtration that means less chlorine to be added. Floods and heavy rainfalls may increase concentrations of organic precursors of DBPs in surface waters [14]. On the other hand they cause higher nutrient concentrations which can promote algal and cyanobacterial blooms. Chen et al. [78] showed that DBPs precursors originating from high cyanobacterial densities can account for significant percentages of the total DBPs formation potential.

Increased floods and rainfalls will alter the transport, transfer, deposition and fate of chemical contaminants in coastal waters. Bioavailability of specific contaminants (e.g. metals) is greatly affected by salinity $[79,80]$. Numerous studies have shown an increasing metal uptake by diverse aquatic organisms at reduced salinities [81-83]. Other studies have shown that solubility of many PAHs depends on salinity in the ambient water [84]. Thus, floods and 
rainfalls will regulate the extent of exposure to toxic substances of seafood, hence of its consumers.

Unfortunately there is still little published evidence demonstrating a causal effect of chemical contamination on the pattern of morbidity following flooding events. But it is expected that floodings and heavy rainfalls, having implications for residue levels in food crops, food animals [85] and water bodies [86], will increase human exposure to chemical contaminants.

\section{Temperature}

It is well known that temperature influences physic chemical equilibriums and biological reactions. Chemical reactions can be doubled for a temperature increase of $10{ }^{\circ} \mathrm{C}$. As a consequence, higher water temperature will determine an increase of dissolution, solubilization, complexation, degradation, evaporation. Hence higher temperatures will lead to higher concentration of dissolved substances in water but will also favor an increase of volatilization of chemicals.

Considering the specific issue of pesticides, higher temperature will exert contrasting impacts, from one side higher degradation and volatilization [75] whch often will cause a more intensive use of them to fight pests risk - but from the other side, more solubilization in water. It is likely that changes in land use, induced by higher temperature, might play a more significant effect on pesticides in the environment than transformation and repartition processes [75]. For example, an increased prevalence of pests, weeds and diseases may lead to wider and more frequent application of both pesticides and veterinary medicines [28, 75].

Higher temperature in the Oceans may increase human exposure to mercury, especially in geographical areas where the population diet is based on seafood. Mercury is a global pollutant and is a reason of concern for public health when it is elevated above natural background levels, mainly through anthropogenic causes [87]. Mercury seems methylated by biotic processes [88]. Monomethyl mercury bioaccumulates and biomagnifies at all trophic levels in the food chain and can have severe neurological effects. Mercury methylation rates are temperature dependent [89]. Usually $80-99 \%$ of mercury found in fish muscle tissue is methyl mercury, regardless of its concentration in the environment [89]. It is expected that ocean temperature changes will increase the number of people exposed to above the tolerable weekly intakes defined by WHO for mercury [90].

Increased temperatures of natural surface waters used as drinking water supplies promote the DBPs formation rate [14]. Rodriguez and Serodes [91] showed that thrialomethanes (THM) concentrations vary from 1.5 to 2 times, depending on the utility, between drinking water plant and tap. In the same way, others authors reported that increasing temperature $\left(10-33{ }^{\circ} \mathrm{C}\right)$ generally increased the formation of bromoorganic DBPs [92].

\section{Droughts}

Hotter, drier summers and increasingly severe and frequent droughts will deplete river flows, reducing contaminant dilution capacity and leading to elevated concentrations of hazardous substances [27]. Dry periods may entail brief spikes of compounds from sewage effluents, which can provoke transient perturbation of river ecosystems [93], with possible implications for human health. Increased contaminant concentrations are expected also in groundwater aquifers, especially in the unconfined ones.

Connected to water shortage is the particular case of temporary rivers. These are characterized by periodic dry phase and are a significant percentage of total river length in the world (between 40 and 70\%). They are dominant in the semiarid Mediterranean area [94], where they represent an important source of water. These ecosystems are particularly exposed to the alteration of hydrological cycle due to longer drought periods associated with intense runoff and flushing [16], which can bring particularly high concentrations of pathogenic microorganisms and chemicals. The rising interest in their ecology during the last decade has highlighted their importance as links between water stored in soils, aquifers, snowpack, glaciers, vegetation and the atmosphere [95]. Recently, it has also been shown that they are important spots of nutrient and carbon recycling during the dry period $[96,97]$. These processes are strictly related to the biochemistry of hazardous substances, entered the river along the hydrographic basin. Increasing frequency and duration of alternated dryheavy rain periods, due to climate changes, by altering the timing of these processes is definitely going to affect the impact on the coastal environments of the catchments. Whether in a positive or negative way, there are not enough data yet [98].

\section{CYANOBACTERIA}

Health risks due to the toxins produced by cyanobacteria, photosynthetic prokaryotes diffuse in all the habitats, especially the aquatic ones, have been extensively addressed in this same issue of Annali dell'Istituto Superiore di Sanità by Manganelli et al., p. 415 [99]. Briefly, cyanotoxins have different toxicological profiles, and target different organs. Several environmental factors affect their production, but mechanisms are still unknown. Humans can be exposed to cyanotoxins via ingestion (drinking and bathing water, through aquatic food chain), via aerosol and via parenteral, if surface contaminated water is used for haemodialysis [99]. Climate changes effects will be summed up with the effects of other environmental variables on cyanobacterial fitness and toxicity, with different outcomes, depending on the species/strain and the environment (i.e. lake, river, seawater). Available data are mostly obtained in laboratory studies or using mesocosm systems, even providing conflicting results: in many cases the apparent discrepancy could be attributed to the diverse response to climate change of differ- 
ent cyanobacterial species, strongly depending on their physiological or ecological features, or, in the case of field studies, to the different response of the water body. It is therefore not possible to draw some general behaviours for the entire class of cyanobacteria and separated analyses should be carried out depending on the species and the environment. Bearing in mind these considerations, it is possible, at present, only summarize the available information in the following as shown in Figure 2.

\section{Heavy rainfall and floods}

Changes in freshwater runoff will have the greatest potential impacts on estuaries, causing changes in physical mixing characteristics [100]. Freshwater inflows into estuaries influence water residence time, nutrient delivery, vertical stratification, salinity, and control of phytoplankton growth rates [101]. Increased freshwaters inputs from increased runoff can dilute the estuarine environment by lowering salinity and promote extremely large blooms of toxic cyanobacteria by carrying inocula of salt-tolerant cyanobacteria from inland rivers. A combination of a particularly strong freshwater inflow after one day of unusual heavy rainfall with high temperature and the right nutrient concentration, favoring fast growth rate, has been the cause for a very large bloom of Microcystis aeruginosa in the Swan River Estuary, West Australia, in February 2000 [102].

Since increasing salinities can induce cell lyses and/ or extracellular release of toxins [103], an indirect effect of heavy rainfall/floods, by conveying toxic cyanobacteria to brackish coastal waters, can be an increase in the extracellular quota of toxins. In 2005 in St. Lucie River Estuary, one of the largest brackish water systems on the East Coast of Florida, a periods of heavy rainfall caused the washout of $M$. aeruginosa cells into the estuary, suddenly covered by a dense bloom: the abrupt change in salinity (32\%o) caused an increase of $80 \%$ of toxin release in water [104]. Heavy rainfall and floods enhance the possibility of cyanobacteria expansion into coastal environments, thus increasing the exposure of edible organisms [99]. It is worth noting that heavy rain and floods can increase the nutrient availability of lakes, that in turn induce cyanobacterial proliferation. In Bangladesh, where a heavy rainfall drained phosphorus from the surrounding paddy fields into an aquaculture ponds, the increased nutrient concentration $\left(9.5 \mathrm{mg} \mathrm{L}^{-1}\right)$ coincident with high temperature $\left(31^{\circ} \mathrm{C}\right)$ was the possible cause of a bloom of Microcystis aeruginosa and Aphanizomenon flosaquae [105]. Soil runoff and discharge from wastewater treatment plants, rich in phosphorus, iron and carbon, might be responsible for the spreading of the mat-forming nitrogen-fixing Lyngbya maiuscula in coastal Queensland [106-107]. In Denmark the increase in phosphorus loading from land to lakes and coastal areas is expected to increase by 3 to $16 \%$ in the next $100 \mathrm{yr}$, due to higher winter rainfall; a shift in lakes community has already been observed towards dominance of cyanobacteria and dinoflagellates vs. diatoms and crysophytes [108].

\section{Temperature}

Increasing temperature in eutrophic condition can directly increase cyanobacterial proliferation and can be a main factor for their poleward movements and possibly their toxicity [109]. Indeed, some cyanobacteria like Microcystis, Anabaena and Oscillatoria have higher growth rate at higher temperature with respect to diatoms [110-112] and temperature can be one of the main factor in determining the success of one species $v s$ other cyanobacteria or other phyto-

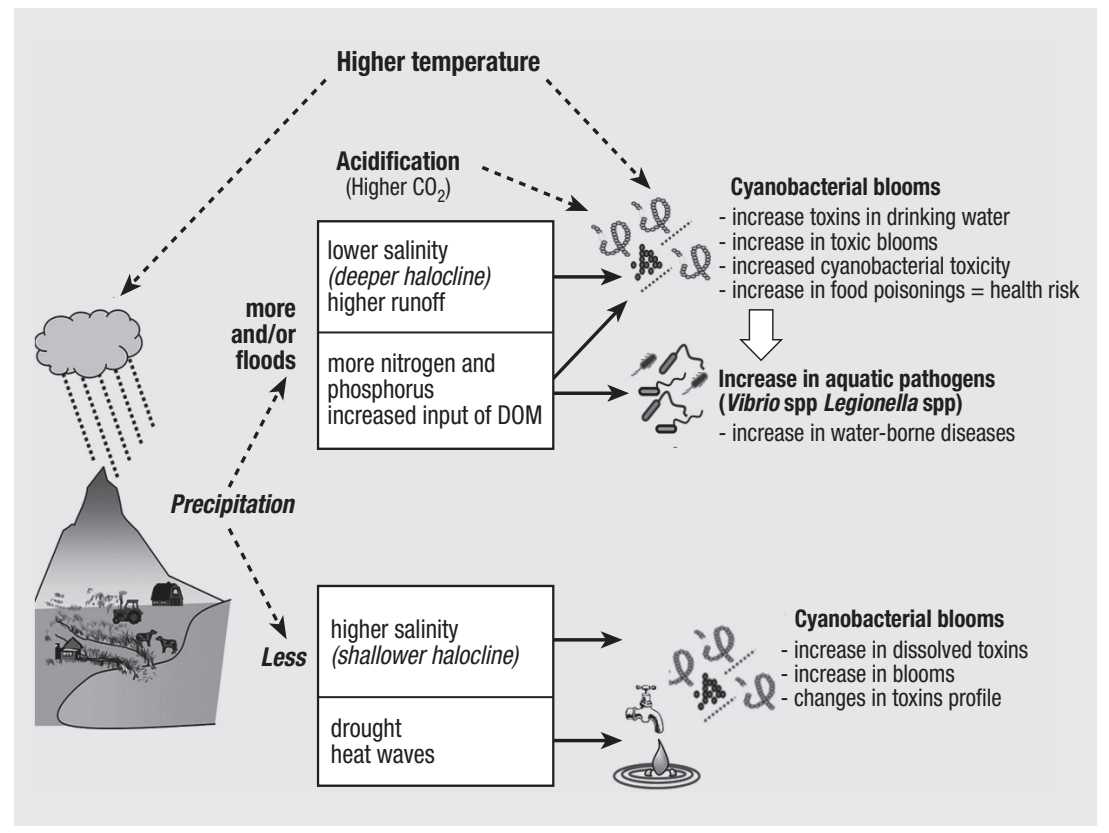

Fig. 2 | Schematic diagram depicting the interrelations between changing meteorological parameters and toxic cyanobacteria. 
plankton, if nutrients concentration is not limiting [113-115].

It is expected that the warming trend will move forward the onset of spring bloom in high latitude and temperate areas [116] and will accelerate the spread and abundance of subtropical species to temperate regions all over the world. Cylindrospermopsis raciborskii is probably the best known example. It was originally found in the tropics, in central Africa and Australian lakes; at present, starting from the mid $90 \mathrm{~s}$, it has been reported in several temperate areas, in Europe and central America. Climate change is one of the factors considered in explaining its diffusion $[117,118]$. Notwithstanding the areal expansion, the risk due to the exposure to $C$. raciborskii cannot be directly inferred and it is not straightforward that it will increase, since the toxins produced in different continents are different: the Australian strains produce cylindrospermopsin [119], whereas the Brazilian or European strains produce saxitoxins and a still unknown toxin, respectively [120, 121].

Another example of expected larger diffusion of tropical species is that of Trichodesmium spp. in seawater. Temperature dependence of $\mathrm{O}_{2}$ flux and respiration seems to be the main reason for this non heterocystous $\mathrm{N}_{2}$ fixing species to be dominant in subtropical and tropical ocean regions [122]. The reduced $\mathrm{O}_{2}$ flux in warm seawater and the high respiration rate at high temperature allow Trichodesmium to outcompete other heterocystous species. It has been estimated that the poleward shift of the $20^{\circ} \mathrm{C}$ isothermal as a consequence of a $3{ }^{\circ} \mathrm{C}$ increase by 2090, which poses a lower limit to the distribution of Trichodesmium, will expand its range of $11 \%$, even if this will be counteracted by the reduction of $16 \%$ of its thermal niche at the tropics, where temperature is expected to exceed $30{ }^{\circ} \mathrm{C}$, corresponding to suboptimal growth rates [123]. It is therefore reasonable to expect a poleward shift of this species, being all the other parameters unchanged.

Complex interactions between direct and indirect effects of temperature are more often the cause of shifts in community composition and changes in dominant species. Increasing thermal stability and stratification in deep, eutrophic lakes will favor the proliferation of buoyant cyanobacteria, like Microcystis, Anabaena, Aphanizomenon, and elevate the chance for the development of surface blooms [124]. Milder winter in temperate eutrophic lakes, may indirectly favor also Oscillatoriales bloom, by inducing a complex shift in phytoplankton community composition [125].

The observed significant increase in cyanobacterial biomass over the years in the Baltic Sea, composed mainly by Aphanizomenon flos-aquae, Nodularia spumigena and Anabaena sp., has been correlated to increased temperature, to variation in the hydrology, and to nutrients inputs [126]. Hence a general higher exposure of aquatic organisms, and possibly of their consumers, human beings included, can be foreseen.
Data available indicate that the prolonged thermal stratification, due to warming climate, would favor also species like Planktothrix rubescens [127], which are usually more adapted to colder water.

Data on incresing temperature effects on toxicity are controversial, and depend on the co-occurrence of other parameters, like light and nutrients [128129]. Davis et al. [129] showed that in 4 lakes in Northeast US, higher temperature (and phosphorus concentration) favored an increase of microcystins MCs production by stimulating the growth rate of Microcystis spp. toxic cells [129]. During the last decade, the rise of minimal surface temperature of many reservoirs and water basin in South Africa seems to be the direct cause of the proliferation and bloom of toxic cyanobacteria, since there has been a correlated increase of animal mortalities in several areas [130].

In Oscillatoria agardhii isolated from Finnish lakes MCs production rate peaked at optimum growth temperature in one strain $\left(25^{\circ} \mathrm{C}\right)$ and was constant in the range $15-25^{\circ} \mathrm{C}$ in a second one. However, for both strains, growth and toxin production decreased at $30^{\circ} \mathrm{C}$ [131]. On the contrary, for Microcystis aeruginosa increasing temperature from $18^{\circ} \mathrm{C}$ to $28^{\circ} \mathrm{C}$, yielded higher growth rates, but reduced toxicity of the cultured strains [132]. Also the production of cylindrospermopsin CYN seems to be inhibited by higher temperature in tropical Cylindrospermopsis [119] and in temperate Aphanizomenon [133].

Additionally, temperature can impact on toxicity by affecting the variants profile of toxin production, as it happened in an Aphanizomenon sp. cultured strain, which following an increase of $\mathrm{T}$ from 22 to $28{ }^{\circ} \mathrm{C}$, switched towards the production of the more toxic variant among the 4 detected toxins [134].

In two strains of Anabaena from a lake in Southern Finland, temperature higher and lower than the optimum $\left(25^{\circ} \mathrm{C}\right)$ decreased the total amount of MCs production. In addition the profile of MCs variants changed: high light and high temperature favored the production of the less toxic - $R R$ variant, while an increase in - LR variant was observed at lower temperature [135].

\section{Droughts}

The likely longer dryness periods, increasing in some regions at mid-latitudes and in the dry tropics, some of which already water-stressed areas, may influence cyanobacterial proliferation by increasing nutrient availability (higher concentrations due to surface water evaporation in summer) and reducing water bodies flow (thus increasing the areas of still waters in which cyanobacterial growth is easier). One of the largest bloom of Anabaena circinalis involved more than $1000 \mathrm{~km}$ of one of Australia's major river systems, in a very low flow conditions, concurrent with high nutrients concentration and high temperature [136]. 
Another important consequence of droughts is that rainfall following period of dryness, can transport cyanotoxins into groundwater, beneath parched and cracked soil, thus contaminating very precious sources of drinking water.

Changes in phytoplankton communities of coastal environment exposed to a reduction in freshwater discharge and to saltwater intrusion, can eliminate more sensitive species and favor more tolerant cyanobacteria and expose aquatic organisms to higher concentration of dissolved cyanotoxins [103].

In Nebraska lakes a lower water quality due to the presence of MCs, associated with the drought conditions and lower nitrogen:phosphorus ratios [137], was reported during 2004, concomitant with dogs, wildlife and livestock deaths, and more than 50 accounts of human skin rashes, lesions, or gastrointestinal illnesses.

\section{CONCLUSIVE REMARKS}

Reviewed data show that increase of water temperature, heavy rains, floods and droughts will increase the distribution and patterns of human exposures to pathogens, chemicals and cyanobacteria. Several studies have shown the association between heavy rainfalls/floods and outbreaks of waterborne diseases. The number and severity of these outbreaks are destined to increase. In particular, zoonotic infections will likely increase as a consequence of washing into water of wild animal and livestock faeces due to heavy rain falls and floods. Different strains of enteric viruses and protozoa will increase their concentrations in water bodies representing etiological pathogens not signaled by conventional faecal contamination indicators.

Several outbreaks have been reported due to groundwater contamination by pathogens as a consequence of drought, that has lowered the water table, resulting in changes in underground water flows of surface water into groundwater.

Increasing temperature could favor the growth of some pathogenic indigenous bacteria, like Vibrio parahaemolyticus, V. vulnificus and $V$. alginolyticus, which are already among the most common etiological agents responsible for diseases transmitted by seafood consumption in US. Increasing temperatures are expected to expand the range and increase the prevalence of $V$. cholerae and cholera, whose diffusion will also be favored by the destructive effects of floods and hurricane on water distribution systems.

Heavy rainfalls and floods will increase the release of chemical constituents from minerals and their concentrations in natural waters, including that of elements like As and F, that at high levels are dangerous for human health. Similarly they will increase concentrations of precursors of DBPs, leading to higher exposures through drinking water consumption. Higher temperature in the oceans may increase human exposure to methyl mercury, especially in geographical areas where the population diet is based on seafood, increasing the number of people above the tolerable weekly intake defined by WHO.

Increased temperatures and floods will promote the formation rate of DBPs.

Heavy rainfalls and floods will expand the distribution of freshwater cyanobacteria into brackish and coastal waters, by physical transport of cyanobacterial blooms into estuaries and by altering the chemical and physical conditions of those areas, ultimately affecting the composition of phytoplankton. These effects will increase the risk of exposure of seafood to cyanotoxins, which is going to be one of the new scenarios of exposure.

Also temperature will affect the geographical distribution of tropical toxic species, that will move towards temperate latitudes, where water temperature is expected to increase. Many deep eutrophic lakes are likely to be dominated by buoyant cyanobacteria, by the protraction of water stratification, which will prolong the period of exposure.

Of course the above predictions do not consider the role of management measures that can be implemented to counteract the worsening scenario, especially to mitigate the effects of extreme events. For these factors, the main focus is identifying regions most at risk of flooding and preparing plans for responding and mitigating the main consequences, as stated in the European directive on management of floods [138].

Many Countries worldwide are strengthening their ability to cope with these events improving their early warning systems, vulnerability assessment and response plan to emergency, still we need a more coordinated approach among different operators (environmental, public and veterinary health, water managers, utilities sectors, land use managers) to counteract water unsafety.

WBDs health surveillance, post extreme events environmental and biota monitoring of affected areas, efficiency of waste water treatment are also crucial areas of action for adaptation measures as well as training of professionals involved at local level on new risk scenarios of WBDs.

If the increase of temperature and extreme events is a result of global warming due to human activities, losses, damages, increased burden of diseases could continue rising indefinitely. Long term measures to counteract the impact of climate change on human health rely on a sound strategy aimed at reducing green house gases emissions.

\section{Conflict of interest statement}

There are no potential conflicts of interest or any financial or personal relationships with other people or organizations that could inappropriately bias conduct and findings of this study.

Submitted on invitation.

Accepted on 24 September 2012. 


\section{References}

1. World Health Organization - World Meteorological Organization. Atlas of health and climate. Geneva: WHO, WMO; 2012. Available from: http://www.wmo.int/ebooks/ WHO/Atlas_EN_web.pdf.

2. EM-DAT. EM-DAT international disaster database. Brussels: Universite Catholique de Louvain Centre for Research on the Epidemiology of Disasters (CRED); 2010. Available from: www.emdat.be/database.

3. Field CB, Barros V, Stocker TF, Qin D, Dokken DJ, Ebi KL, et al. (Ed.). IPCC 2012. Managing the risks of extreme events and disasters to advance climate change adaptation. A special report of the intergovernmental panel on climate change. Cambridge, UK, and New York, NY, USA: Cambridge University Press; 2012.

4. Bates BC, Kundzewicz ZW, Wu S, Palutikof JP(Ed.). Climate change and water. Technical paper of the intergovernmental panel on climate change. Geneva: IPCC Secretariat; 2008.

5. Evans C, Monteith D, Cooper D. Long-term increases in surface water dissolved organic carbon: observations, possible causes and environmental impacts. Env Poll 2005;137:5571. http://dx.doi.org/10.1016/j.envpol.2004.12.031

6. Gaume E, Bain V, Bernardara P, Newinger O, Barbuc $\mathrm{M}$, Bateman A, et al. A compilation of data on European flash floods. J Hydrol 2009;367(1-2):70-8. http://dx.doi.org/10.1016/j.jhydrol.2008.12.028

7. Menne B. Impacts of climate change and extreme events on waterborne disease. In: Sinisi L, Aertgeerts R (Ed.). Guidance on water supply and sanitation in extreme weather events. Copenhagen: UNECE/WHO; 2011.

8. OzCoasts. Saline intrusion. Canberra ACT: OzCoast Australian Online Coastal Information; 2010. Available from: www.ozcoasts.org.au/indicators/saline_intrusion.jsp.

9. Komatsu E, Fukushima T, Harasawa H. A modeling approach to forecast the effect of long-term climate change on lake water quality. Ecol Modell 2007;209(2-4):351-66. http://dx.doi.org/10.1016/j.ecolmodel.2007.07.021

10. van Vliet MTH, Zwolsman JJG. Impact of summer droughts on the water quality of the Meuse river. J Hydrol 2008;353(1-2):1-17.

http://dx.doi.org/10.1016/j.jhydrol.2008.01.001

11. Zwolsman JJG, Bokhoven AJv. Impact of summer droughts on water quality of the Rhine River - a preview of climate change? Anglais 2007;56(4):45-55. http://dx.doi.org/10.2166/wst.2007.535

12. Malmaeus JM, Blenckner T, Markensten H, Persson I. Lake phosphorus dynamics and climate warming: A mechanistic model approach. Ecol Modell 2006;190(1-2):1-14. http://dx.doi.org/10.1016/j.ecolmodel.2005.03.017

13. George G, Hurley M, Hewitt D. The impact of climate change on the physical characteristics of the larger lakes in the English Lake District. Freshwater Biol 2007;52(9):1647-66. http://dx.doi.org/10.1111/j.1365-2427.2007.01773.x

14. Delpla I, Jung AV, Baures E, Clement M, Thomas O. Impacts of climate change on surface water quality in relation to drinking water production. Environ Int 2009;35(8):1225-33. http://dx.doi.org/10.1016/j.envint.2009.07.001

15. Bindoff NL, Willebrand J, Artale V, Cazenave A, Gregory J, Gulev S, et al. Observations: oceanic climate change and sea level. In: Solomon S, Qin D, Manning M, Chen Z, Marquis M, Averyt KB, et al. (Ed.). Climate change 2007: The physical science basis contribution of working group I to the fourth assessment report of the intergovernmental panel on climate change. Cambridge, United Kingdom and New York, NY, USA: Cambridge University Press; 2007.
16. Milly PCD, Dunne KA, Vecchia AV. Global pattern of trends in streamflow and water availability in a changing climate. Nature 2005;438:347-50. http://dx.doi.org/10.1038/nature04312

17. UNSW. Potential impacts of sea-level rise and climate change in coastal aquifers. Sydney, NSW: University of New South Wales; 2010. Available from: www.connectedwaters.unsw. edu.au/resources/articles/coastal_aquifers.html.

18. Semenza JC, Menne B. Climate change and infectious diseases in Europe. Lancet Infect Dis 2009;9(6):365-75. http://dx.doi.org/10.1016/S1473-3099(09)70104-5

19. World Health Organization. Guidelines for drinking-water quality: incorporating 1st and 2nd addenda. Geneva: WHO; 2008.

20. Rosen B. Waterborne pathogens in agricultural watersheds. Burlington, Vt.: USDA-NRCS Watershed Institute, University of Vermont; 2000.

21. Hurst CJ. Overview of water microbiology as it relates to public health. In: Hurst CJ, Crawford RL, Garland JL, Lipson DA, Mills AL, Stetzenbach LD (Ed.). Manual of environmental microbiology. Third edition. Washington, DC: ASM Press; 2007. p. 219-21.

22. Hunter P. Climate change and waterborne and vectorborne disease. J Appl Microbiol 2003;94:37-46. http://dx.doi.org/10.1046/j.1365-2672.94.s1.5.x

23. Nie L, Lindholm O, Braskerud B. Urban flood management in a changing climate. $J$ Water 2009;2:203-13.

24. Hilscherova K, Dusek L, Kubik V, Cupr P, Hofman J, Klanova J, et al. Redistribution of organic pollutants in river sediments and alluvial soils related to major floods. $J$ Soil Sed 2007;7(3):167-77.

http://dx.doi.org/10.1065/jss2007.04.222

25. Nagels JW, Davies-Colley RJ, Donnison AM, Muirhead RW. Faecal contamination over flood events in a pastoral agricultural stream in New Zealand. Water Sci Technol 2002;45(12):45-52.

26. Muirhead RW, Davies-Colley RJ, Donnison AM, Nagels JW. Faecal bacteria yields in artificial flood events: quantifying in-stream stores. Water Res 2004;38(5):1215-24. http://dx.doi.org/10.1016/j.watres.2003.12.010

27. European Environment Agency. Hazardous substances in Europe's fresh and marine waters. An overview. Luxembourg: EEA; 2011. (Technical report n. 8/2011).

28. Boxall AB, Hardy A, Beulke S, Boucard T, Burgin L, Falloon PD, et al. Impacts of climate change on indirect human exposure to pathogens and chemicals from agriculture. Environ Health Perspect 2009;117(4):508-14. http://dx.doi.org/10.1289/ehp.0800084

29. Maalouf H, Pommepuy M, Le Guyader F. Environmental conditions leading to shellfish contamination and related outbreaks. Food Environ Virol 2010;2(3):136-45. http://dx.doi.org/10.1007/s12560-010-9043-4

30. King BJ, Monis PT. Critical processes affecting Cryptosporidium oocyst survival in the environment. Parasitology 2007;134:309-23. http://dx.doi.org/10.1017/S0031182006001491

31. Howe AD, Forster S, Morton S, Marshall R, Osborn KS, Wright $\mathrm{P}$, et al. Cryptosporidium oocysts in a water supply associated with a cryptosporidiosis outbreak. Emerging Infect Dis 2002;8:619-24.

32. Kistemann T, Claßen T, Koch C, Dangendorf F, Fischeder $\mathrm{R}$, Gebel J, et al. Microbial load of drinking water reservoir tributaries during extreme rainfall and runoff. Appl Environ Microbiol 2002;68(5):2188-97. http://dx.doi.org/10.1128/aem.68.5.2188-2197.2002 
33. Auld H, MacIver D, Klaassen J. Heavy rainfall and waterborne disease outbreaks: the walkerton example. $J$ Toxicol Environ Health 2004;67(20):1879-87.

http://dx.doi.org/10.1080/15287390490493475

34. Thurston-Enriquez JA, Gilley JE, Eghball B. Microbial quality of runoff following land application of cattle manure and swine slurry. $J$ Water Health 2005;3:157-71.

35. Mons C, Dumetre A, Gosselin S, Galliot C, Moulin L. Monitoring of Cryptosporidium and Giardia river contamination in Paris area. Water Research 2009;43:211-7. http://dx.doi.org/10.1016/j.watres.2008.10.024

36. Nichols G, Lane C, Asgari N, Verlander NQ, Charlett A. Rainfall and outbreaks of drinking water related disease in England and Wales. $J$ Water Health 2009;7:1-8. http://dx.doi.org/10.2166/wh.2009.143

37. Mac Kenzie WR, Hoxie NJ, Proctor ME, Gradus MS, Blair KA, Peterson DE, et al. A massive outbreak in Milwaukee of cryptosporidium infection transmitted through the public water supply. New Engl J Med 1994;331(3):161-7. http://dx.doi.org/10.1056/NEJM199407213310304

38. Curriero FC, Patz JA, Rose JB, Lele S. The association between extreme precipitation and waterborne disease outbreaks in the United States, 1948-1994. Am J Public Health 2001;91(8):1194-9.

http://dx.doi.org/10.2105/AJPH.91.8.1194

39. Weniger BG, Blaser MJ, Gedrose J, Lippy EC, Juranek DD. An outbreak of waterborne giardiasis associated with heavy water runoff due to warm weather and volcanic ashfall. $A m$ J Public Health 1983;73(8):868-72. http://dx.doi.org/10.2105/AJPH.73.8.868

40. Lisle JT, Rose JB. Cryptosporidium contamination of water in the USA and UK: A minireview. J Water SRT - Aqua 1995;44:103-17.

http://dx.doi.org/10.1289/ehp.00108367

41. Alterholt TB, LeChevalier MW, Norton WD, Rosen JS. Effect of rainfall on giardia and crypto. J Am Water Works Assoc 1998;90:66-80.

42. Rose JB, Daeschner S, Easterling DR, Curriero FC, Lele S, Patz JA. Climate and waterborne disease outbreaks. $J$ Am Water Works Assoc 2000;9:77-87.

43. Patz JA, McGeehin MA, Bernard SM. The potential health impacts of climate variability and change for the United States: Executive summary of the report of the health sector of the U.S. National Assessment. Environ Health Perspect 2000;108:367-76.

44. Hoxie NJ, Davis JP, Vergeront JM, Nashold RD, Blair KA. Cryptosporidiosis-associated mortality following a massive waterborne outbreak in Milwaukee, Wisconsin. Am J Public Health 1997;87(12):2032-5. http://dx.doi.org/10.2105/AJPH.87.12.2032

45. Lake IR, Bentham G, Kovats RS, Nichols GL. Effects of weather and river flow on cryptosporidiosis. $J$ Water Health 2005;3(4):469-74.

46. O'Connor DR. Report of the Walkerton Inquiry. Part 1. The events of may 2000 and related issues. Toronto: 2002.

47. European Food Safety Authority - European Centre for Disease Prevention and Control. The community summary report. Food-borne outbreaks in the European Union in 2007. Brussels, Belgium: EFSA-ECDC; 2009.

48. Said B, Wright F, Nichols GL, Reacher M, Rutter M. Outbreaks of infectious disease associated with private drinking water supplies in England and Wales 1970-2000. Epidemiol Infect 2003;130:469-79. http://dx.doi.org/10.1017/S0950268803008495

49. European Union. Directive 2006/7/EC concerning the management of bathing water quality and repealing Directive 76/160/ EC. Official Journal of the European Union L 64 4/3/2006.
50. Doyle A, Barataud D, Gallay A, Thiolet J, Le Guyaguer S, Kohli E, et al. Norovirus foodborne outbreaks associated with the consumption of oysters from the Etang de Thau, France, December 2002. Euro Surveill 2004;9(3):451.

51. Le Guyader FS, Le Saux J-C, Ambert-Balay K, Krol J, Serais O, Parnaudeau S, et al. Aichi virus, norovirus, astrovirus, enterovirus, and rotavirus involved in clinical cases from a French oyster-related gastroenteritis outbreak. J Clin Microbiol 2008;46(12):4011-7. http://dx.doi.org/10.1128/jcm.01044-08

52. Murphy AM, Grohmann GS, Christopher PJ, Lopez WA, Davey GR, Millsom RH. An Australia-wide outbreak of gastroenteritis from oysters caused by norwalk virus. Med $J$ Aust 1979;2(7):329-33.

53. Morse DL, Guzewich JJ, Hanrahan JP, Stricof R, Shayegani M, Deibel R, et al. Widespread outbreaks of clam- and oyster-associated gastroenteritis. Role of norwalk virus. $N$ Engl J Med 1986;314(11):678-81. http://dx.doi.org/10.1056/NEJM198603133141103

54. Semenza JC, Höser C, Herbst S, Rechenburg A, Suk JE, Frechen $\mathrm{T}$, et al. Knowledge mapping for climate change and food- and waterborne diseases. Crit Rev Environ Sci Technol 2011;42(4):378-411. http://dx.doi.org/10.1080/10643389.2010.518520

55. Schijven JF, de Roda Husman AM. Effect of climate changes on waterborne disease in The Netherlands. Water $\mathrm{Sci}$ Technol 2005;51(5):79-87.

56. Schijven JF, Hassanizadeh SM. Removal of viruses by soil passage: Overview of modeling, processes, and parameters. Crit Rev Environ Sci Technol 2000;30(1):49-127. http://dx.doi.org/10.1080/10643380091184174

57. Lipp EK, Huq A, Colwell RR. Effects of global climate on infectious disease: the cholera model. Clin Microbiol Rev 2002;15(4):757-70.

http://dx.doi.org/10.1128/cmr.15.4.757-770.2002

58. DePaola A, Jones JL, Woods J, Burkhardt W, Calci KR, Krantz JA, et al. Bacterial and viral pathogens in live oysters: 2007 United States market survey. Appl Environ Microbiol 2010;76(9):2754-68

http://dx.doi.org/10.1128/aem.02590-09

59. Centers for Disease Control and Prevention. A Trends in foodborne illness in the United States, 1996-2011. Atlanta, GA: CDC; 2011. Available from: www.cdc.gov/foodnet/data/trends/trends-2011.html.

60. Semenza JC, Herbst S, Rechenburg A, Suk JE, Höser C, Schreiber C, et al. Climate change impact assessment of food- and waterborne diseases. Crit Rev Environ Sci Technol 2011;42(8):857-90. doi:10.1080/10643389.2010.534706.

61. Johnson CN, Flowers AR, Noriea III NF, Zimmerman AM, Bowers JC, DePaola A, et al. Relationships between environmental factors and pathogenic vibrios in the Northern Gulf of Mexico. Appl Environ Microbiol 2010;76(21):7076-84. http://dx.doi.org/10.1128/AEM.00697-10

62. Koelle K, Rodo X, Pascual M, Yunus M, Mostafa G. Refractory periods and climate forcing in cholera dynamics. Nature 2005;436(7051):696-700. http://dx.doi.org/10.1038/nature03820

63. Lafferty KD. The ecology of climate change and infectious diseases. Ecology 2009;90(4):888-900. http://dx.doi.org/10.1890/08-0079.1

64. Wilson K. Climate change and the spread of infectious ideas1. Ecology 2009;90(4):901-2. http://dx.doi.org/10.1890/08-2027.1

65. Menne B, Bertollini R. The health impacts of desertification and drought. Down to Earth 2000;14:4-6.

66. Chu Y, Salles C, Tournoud MG, Got P, Troussellier M, Rodier C, et al. Faecal bacterial loads during flood events 
in Northwestern Mediterranean coastal rivers. Journal of Hydrology 2011;405(3-4):501-11.

http://dx.doi.org/10.1016/j.jhydrol.2011.05.047

67. Rechenburg A, Kistemann T. Sewage effluent as a source of campylobacter sp. in a surface water catchment. Int $J$ Environ Health Res 2009;19(4):239-49.

http://dx.doi.org/10.1080/09603120802460376

68. Willocks L, Crampin A, Milne L, Seng C, Susman M, Gair R, et al. A large outbreak of cryptosporidiosis associated with a public water supply from a deep chalk borehole. Communicable Disease and Public Health 1998;1(4):239-43.

69. Bergmire-Sweat D, Morgan J, Wilson K, VonAlt K, Marengo L, Bennett T, et al. (Ed.). Cryptosporidiosis at Brushy Creek: describing the epidemiology and causes of a large outbreak in Texas, 1998. International Symposium on Waterborne Pathogens. Milwaukee, WI: American Water Works Association; 1999.

70. Leland D, McAnulty J, Keene W, Stevens G. A cryptosporidiosis outbreak in a filtered water supply. $J$ Am Water Works Assoc 1993; 85(6):34-42.

71. Yamamoto N, Urabe K, Takaoka M, Nakazawa K, Gotoh A, Haga M, et al. Outbreak of cryptosporidiosis after contamination of the public water supply in Saitama Prefecture, Japan in 1996. Kansenshogaku Zasshi - J Japan Assoc Infect Dis 2000;74(6):518-26.

72. Rothwell J, Evans M, Daniels S, Allott T. Baseflow and stormflow metal concentrations in streams draining contaminated peat moorlands in the Peak District National Park (UK). J Hydrol 2007;341:90-104 http://dx.doi.org/10.1016/j.jhydrol.2007.05.004

73. Olivie-Lauquet G, Gruau G, Dia A, Riou C, Jaffrezic A, Henin O. Release of trace elements in wetlands: role of seasonal variability. Water Res 2001;35(4):943-52. http://dx.doi.org/10.1016/S0043-1354(00)00328-6

74. Pédrot M, Dia A, Davranche M, Bouhnik-Le Coz M, Henin $\mathrm{O}$, Gruau G. Insights into colloid mediated trace element release at the soil/water interface. J Colloid Interface Sci 2008; 325:187-97. http://dx.doi.org/10.1016/j.jcis.2008.05.019

75. Bloomfield J, Williams R, Gooddy D, Cape J, Guha P. Impacts of climate change on the fate and behaviour of pesticides in surface and groundwater-a UK perspective. $S c i$ Total Environ 2006;369:163-77. http://dx.doi.org/10.1016/j.scitotenv.2006.05.019

76. Harmon S, Wyatt D. Evaluation of post Katrina flooded soils for contaminants and toxicity to the soil invertebrates Eisenia fetida and Caenorhabditis elegans. Chemosphere 2008;70(10):1857-64. http://dx.doi.org/10.1016/j.chemosphere.2007.08.007

77. Fawell J. Chemicals in the water environment. Where do the real and future threats lie? Ann Ist Super Sanità 2012;48(4):347-53.

78. Chen C, Zhang X-J, Zhu L-x, Liu J, He W-j, Han H-d. Disinfection by-products and their precursors in a water treatment plant in North China: seasonal changes and fraction analysis. Sci Total Environ 2008;397:140-7. http://dx.doi.org/10.1016/j.scitotenv.2008.02.032

79. McLusky DD, Bryant V, Campell R. The effect of temperature and salinity on the toxicity of heavy metals to marine and estuarine invertebrates. Oceanographic Marine Biology Annual Reviews 1986;24:481-520.

80. Depledge M. Interactions between heavy metals and physiological processes in estuarine invertebrates. In: Chambers PL, Chambers CM (Ed). Estuarine Ecotoxicology. Japaga; 1990. p. 89-100.
81. Hall Jr. LW, Anderson RD. The influence of salinity on the toxicity of various classes of chemicals to aquatic biota. Crit Revi Toxicol 1995;25:281-346. http://dx.doi.org/10.3109/10408449509021613

82. Wright DA. Trace metals and major ion interactions in aquatic animals. Marine Poll Bull 1995;31:8-18. http://dx.doi.org/10.1016/0025-326X(95)00036-M

83. Lee B-G, Wallace WG, Luoma SN. Uptake and loss kinetics of $\mathrm{Cd}, \mathrm{Cr}$ and $\mathrm{Zn}$ in the bivalves Poamocorbula amurenis and Macoma balthica: effects of size and salinity. Mar Ecol Prog Ser 1998;175:177-89. http://dx.doi.org/10.3354/meps175177

84. Ramachandran S, Sweezey MJ, Hodson PV, Boudreau $\mathrm{M}$, Courtenay SC, Lee K, et al. Influence of salinity and fish species on PAH uptake from dispersed crude oil. Marine Poll Bull 2006;52:1182-9. http://dx.doi.org/10.1016/j.marpolbul.2006.02.009

85. Casteel M, Sobsey M, Mueller J. Fecal contamination of agricultural soils before and after hurricane- associated flooding in North Carolina. J Environ Sci Health A 2006;41(2):173-84. http://dx.doi.org/10.1080/10934520500351884

86. Donald D, Hunter F, Sverko E, Hill B, Syrigiannis J. Mobilization of pesticides on an agricultural landscape flooded by a torrential storm. Environ Toxicol Chem 2005;24(1):2-10. http://dx.doi.org/10.1897/03-668.1

87. Boening DW. Ecological effects, transport, and fate of mercury: a general review. Chemosphere 2000;40(12):1335-51. http://dx.doi.org/10.1016/S0045-6535(99)00283-0

88. United Nations Environment Programme. Global mercury assessment. Geneva: UNEP; 2002.

89. Downs S, MacLeod C, Lester J. Mercury in precipitation and its relation to bioaccumulation in fish: a literature review. Water Air Soil Poll 1998;108:149-87.

90. Booth S, Zeller D. Mercury, food webs, and marine mammals: implications of diet and climate change for human health. Environ Health Perspect 2005;113(5):521-6. http://dx.doi.org/10.1289/ehp.7603

91. Rodriguez M, Serodes J. Spatial and temporal evolution of trihalomethanes in three water distribution systems. Water Res 2001;35:1572-86.

http://dx.doi.org/10.1016/S0043-1354(00)00403-6

92. Zhang X, Echigo S, Lei H, Smith M, Minear R, Talley J. Effects of temperature and chemical addition on the formation of bromoorganic DBPs during ozonation. Water Res 2005;39:423-35. http://dx.doi.org/10.1016/j.watres.2004.10.007

93. Proia L, Vilches C, Boninneau C, Kantiani L, Farré M, Romaní AM, etal. Droughtepisodemodulates the response of river biofilms to triclosan. Aquatic Toxicol 2012 (in press). http://dx.doi.org/10.1016/j.aquatox.2012.01.006

94. Guys CM, O'Keeffe J. Simple words and fuzzy zones: early directions for temporary river research in South Africa. Environ Manage 1997;21:517-31.

95. Larned ST, Datry T, Arscott DB, Tockner K. Emerging concepts in temporary-river ecology. Freshwater Biol 2010;55(4):717-38. http://dx.doi.org/10.1111/j.1365-2427.2009.02322.x

96. Zoppini A, Amalfitano S, Fazi S, Puddu A. Dynamics of a benthic microbial community in a riverine environment subject to hydrologicalfluctuations(MulargiaRiver,Italy). Hydrobiologia 2010;657:37-51. http://dx.doi.org/10.1007/s10750-010-0199-6

97. Zoppini A, Marxsen J. Importance of extracellular enzymes for biogeochemical processes in temporary river sediments during fluctuating dry-wet conditions. In: Shukla G, Varma A (Ed.). Soil enzymology. Berlin Heidelberg: Springer; 2011. p. 103-17. http://dx.doi.org/10.1007/978-3-642-14225-3_6 
98. Ademollo N, Capri S, Patrolecco L, Puddu A, Polesello S, Rusconi M, et al. Fate and monitoring of hazardous substances in temporary rivers. TrAC Trends in Analytical Chemistry 2011;30(8):1222-32. http://dx.doi.org/10.1016/j.trac.2011.05.002

99. Manganelli M, Scardala S, Stefanelli M, Palazzo F, Funari E, Vichi S, et al. Emerging Health Issues Of Cyanobacterial Blooms. Ann Ist Super Sanità 2012;48(4):415-28.

100. Scavia D, Field JC, Boesch DF, Buddemeier R, Cayan DR, Burkett V, et al. Climate change impacts on US coastal and marine ecosystems. Estuaries 2002;25:149-64.

101. Moore MV, Pace ML, Mather JR, Murdoch PS, Howarth $\mathrm{RW}$, Folt CL, et al. Potential effects of climate change on freshwater ecosystems of the new england/mid-atlantic region. Hydrological Processes 1997;11(8):925-47. http://dx.doi.org/10.1002/(sici)1099-1085(19970630)11:8<925:: aid-hyp512>3.0.co;2-x

102. Robson BJ, Hamilton DP. Summer flow event induces a cyanobacterial bloom in a seasonal Western Australian estuary. Marine Freshwater Res 2003;54(2):139-51. http://dx.doi.org/10.1071/MF02090

103. Tonk L, Bosch K, Visser PM, Huisman J. Salt tolerance of the harmful cyanobacterium Microcystis aeruginosa. Aquat Microb Ecol 2007;46(2):117-23.

http://dx.doi.org/10.3354/ame046117

104. Ross C, Santiago-Vázquez L, Paul V. Toxin release in response to oxidative stress and programmed cell death in the cyanobacterium Microcystis aeruginosa. Aquatic Toxicol 2006;78(1):66-73.

http://dx.doi.org/10.1016/j.aquatox.2006.02.007

105. Jewel M, Affan M, Khan S. Fish mortality due to cyanobacterial bloom in an aquaculture pond in Blangadesh. Pakistan J Biological Sci 2003;6(12):1046-50.

106. Elmetri I, Bell PRF. Effects of phosphorus on the growth and nitrogen fixation rates of Lyngbya majuscula: implications for management in Moreton Bay, Queensland. Mar Ecol Prog Ser 2004;281:27-35.

http://dx.doi.org/10.3354/meps281027

107. Albert S, O’Neil JM, Udy JW, Ahern KS, O’Sullivan CM, Dennison WC. Blooms of the cyanobacterium Lyngbya majuscula in coastal Queensland, Australia: disparate sites, common factors. Marine Poll Bull 2005;51(1-4):428-37. http://dx.doi.org/10.1016/j.marpolbul.2004.10.016

108. Jeppesen E, Kronvang B, Meerhoff M, Søndergaard M, Hansen KM, Andersen HE, et al. Climate change effects on runoff, catchment phosphorus loading and lake ecological state, and potential adaptations. J Environ Quality 2009;38(5):1930-41. http://dx.doi.org/10.2134/jeq2008.0113

109. Paerl HW, Huisman J. Climate change: a catalyst for global expansion of harmful cyanobacterial blooms. Environ Microbiol Rep 2009;1(1):27-37.

http://dx.doi.org/10.1111/j.1758-2229.2008.00004.x

110. Robarts RD, Zohary T. Temperature effects on photosynthetic capacity, respiration, and growth rates of bloom-forming cyanobacteria. New Zealand $J$ Marine Freshwater Res 1987;21(3):391-9.

http://dx.doi.org/10.1080/00288330.1987.9516235

111. Coles JF, Jones RC. Effect of temperature on photosynthesis-light response and growth of four phytoplankton species isolated from a tidal freshwater river. $J$ Phycol 2000;36(1):7-16.

http://dx.doi.org/10.1046/j.1529-8817.2000.98219.x

112. Paerl HW, Xu H, McCarthy MJ, Zhu G, Qin B, Li Y, et al. Controlling harmful cyanobacterial blooms in a hypereutrophic lake (Lake Taihu, China): The need for a dual nutrient (N \&amp; P) management strategy. Water Res 2011;45(5):1973-83.

http://dx.doi.org/10.1016/j.watres.2010.09.018

113. Nalewajko C, Murphy TP. Effects of temperature, and availability of nitrogen and phosphorus on the abundance of Anabaena and Microcystis in Lake Biwa, Japan: an experimental approach. Limnology 2001;2:45-8. http://dx.doi.org/10.1007/s102010170015

114. Elliott J, Jones I, Thackeray S. Testing the sensitivity of phytoplankton communities to changes in water temperature and nutrient load, in a temperate lake. Hydrobiologia 2006;559(1):401-11. http://dx.doi.org/10.1007/s10750-005-1233-y

115. Chu Z, Jin X, Iwami N, Inamori Y. The effect of temperature on growth characteristics and competitions of Microcystis aeruginosa and Oscillatoria mougeotii in a shallow, eutrophic lake simulator system. Hydrobiologia 2007;581:217-23. http://dx.doi.org/10.1007/s10750-006-0506-4

116. Peeters F, Straile D, Lorke A, Livingstone DM. Earlier onset of the spring phytoplankton bloom in lakes of the temperate zone in a warmer climate. Global Change Biol 2007;13(9):1898-909. http://dx.doi.org/10.1111/j.1365-2486.2007.01412.x

117. Briand JF, Leboulanger C, Humbert JF, Bernard C, Dufour P. Cylindrospermopsis raciborskii (cyanobacteria) invasion at mid-latitudes: selection, wide physiological tolerance, or global warming? JPhycol 2004;40:231-8. http://dx.doi.org/10.1111/j.1529-8817.2004.03118.x

118. Haande S, Rohrlack T, Ballot A, Røberg K, Skulberg R, Beck $\mathrm{M}$, et al. Genetic characterisation of Cylindrospermopsis raciborskii (Nostocales, Cyanobacteria) isolates from Africa and Europe. Harmful Algae 2008;7(5):692-701. http://dx.doi.org/10.1016/j.hal.2008.02.010

119. Saker ML, Griffiths DJ. The effect of temperature on growth and cylindrospermopsin content of seven isolates of Cylindrospermopsis raciborskii (Nostocales, Cyanophyceae) from water bodies in northern Australia. Phycologia 2000;39(4):349-54.

http://dx.doi.org/10.2216/i0031-8884-39-4-349.1

120. Lagos N, Onodera H, Zagatto P, Andrinolo D, Azevedo S, Oshima Y. The first evidence of paralytic shellfish toxins in the fresh water cyanobacterium Cylindrospermopsis raciborskii, isolated from Brazil. Toxicon 1999;37:1359-73. http://dx.doi.org/10.1016/S0041-0101(99)00080-X

121. Fastner J, Heinze R, Humpage AR, Mischke U, Eaglesham GK, Chorus I. Cylindrospermopsin occurrence in two German lakes and preliminary assessment of toxicity and toxin production of Cylindrospermopsis raciborskii (Cyanobacteria) isolates. Toxicon 2003;42(3):313-21.

http://dx.doi.org/10.1016/S0041-0101(03)00150-8

122. Staal M, Meysman FJ, Stal LJ. Temperature excludes N2fixing heterocystous cyanobacteria in the tropical oceans. Nature 2003;425(6957):504-7. http://dx.doi.org/10.1038/nature01999

123. Breitbarth E, Oschlies A, LaRoche J. Physiological constraints on the global distribution of Trichodesmium - effect of temperature on diazotrophy. Biogeosciences 2007;4:53-61. http://dx.doi.org/10.5194/bg-4-53-2007

124. Huisman J, Sharples J, Stroom JM, Visser PM, Kardinaal WEA, Verspagen JMH, et al. Changes in turbulent mixing shift competition for light between phytoplankton species. Ecology 2004;85(11):2960-70. http://dx.doi.org/10.1890/03-0763

125. Shatwell T, Köhler J, Nicklisch A. Warming promotes coldadapted phytoplankton in temperate lakes and opens a loophole for Oscillatoriales in spring. Global Change Biol 2008;14(9):2194-200. http://dx.doi.org/10.1111/j.1365-2486.2008.01630.x 
126. Suikkanen S, Laamanen M, Huttunen M. Long-term changes in summer phytoplankton communities of the open northern Baltic Sea. Estuarine, Coastal and Shelf Science 2007;71(3-4):580-92. http://dx.doi.org/10.1016/j.ecss.2006.09.004

127. Jacquet S, Briand JF, Leboulanger C, Avois-Jacquet C, Oberhaus L, Tassin B, et al. The proliferation of the toxic cyanobacterium Planktothrix rubescens following restoration of the largest natural French lake (Lac du Bourget). Harmful Algae 2005;4(4):651-72. http://dx.doi.org/10.1016/j.hal.2003.12.006

128. Briand E, Yepremian C, Humbert JF, Quiblier C. Competition between microcystin- and non-microcystinproducing Planktothrix agardhii (cyanobacteria) strains under different environmental conditions. Environ Microbiol 2008;10(12):3337-48. http://dx.doi.org/10.1111/j.1462-2920.2008.01730.x

129. Davis TW, Berry DL, Boyer GL, Gobler CJ. The effects of temperature and nutrients on the growth and dynamics of toxic and non-toxic strains of Microcystis during cyanobacteria blooms. Harmful Algae 2009;8(5):715-25. http://dx.doi.org/10.1016/j.hal.2009.02.004

130. Oberholster P, Botha A-M, Myburgh J. Linking climate change and progressive eutrophication to incidents of clustered animal mortalities in different geographical regions of South Africa. African J Biotechnol 2009; 8(21):5825-32.

131. Sivonen K. Effects of light, temperature, nitrate, orthophosphate, and bacteria on growth of and hepatotoxin production by Oscillatoria agardhii strains. Appl Environ Microbiol 1990;56(9):2658-66.
132. Van der Westhuizen AJ, Eloff JN. Effect of temperature and light on the toxicity and growth of the blue-green alga Microcystis aeruginosa (UV-006). Planta 1985;163(1):55-9. http://dx.doi.org/10.1007/bf00395897

133. Preußel K, Wessel G, Fastner J, Chorus I. Response of cylindrospermopsin production and release in Aphanizomenon flos-aquae (Cyanobacteria) to varying light and temperature conditions. Harmful Algae 2009;8(5):645-50 http://dx.doi.org/10.1016/j.hal.2008.10.009

134. Dias E, Pereira P, Franca S. Production of paralytic shellfish toxins by Aphanizomenon sp. LMECYA 31 (cyanobacteria). J Phycol 2002;38(4):705-12. http://dx.doi.org/10.1046/j.1529-8817.2002.01146.x

135. Rapala J, Sivonen K, Lyra C, Niemela S. Variation of microcystins, cyanobacterial hepatotoxins, in Anabaena spp. as a function of growth stimuli. Appl Environ Microbiol 1997; 63(6):2206-12

136. Bowling LC, Baker PD. Major cyanobacterial bloom in the Barwon-Darling River, Australia, in 1991, and underlying limnological conditions. Mar Freshwater Res 1996;47:643-57. http://dx.doi.org/10.1071/MF9960643

137. Walker SR, Lund JC, Schumacher DG, Brakhage PA, McManus BC, Miller JD, et al. Nebraska experience. In: Hudnell HK (Ed.). Cyanobacterial harmful algal blooms: state of the science and research needs. Springer New York; 2008. p. 139-52.

138. Eupean Union. Directive 2007/60/EC, on the assessment and management of flood risks. Official Journal of the European Union L 288 6/11/2007. 
